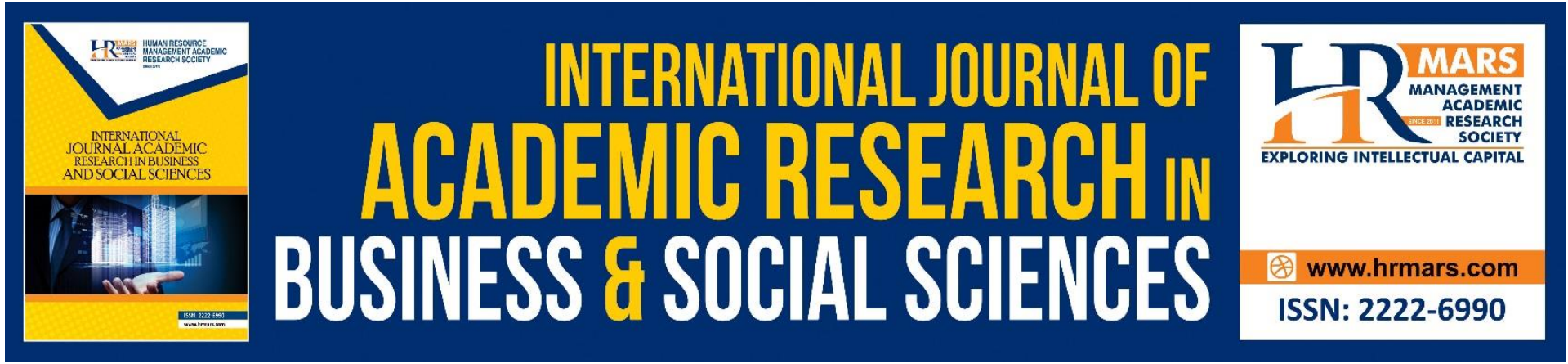

\title{
The Concept of Decolonization in Malaysia: A Philosophy Perspective
}

\section{Nasruddin Yunos and Nazri Muslim}

To Link this Article: http://dx.doi.org/10.6007/IJARBSS/v11-i8/10677

DOI:10.6007/IJARBSS/v11-i8/10677

Received: 07 June 2021, Revised: 29 June 2021, Accepted: 15 July 2021

Published Online: 06 August 2021

In-Text Citation: (Yunos \& Muslim, 2021)

To Cite this Article: Yunos, N., \& Muslim, N. (2021). The Concept of Decolonization in Malaysia: A Philosophy Perspective. International Journal of Academic Research in Business and Social Sciences, 11(8), 13-25.

Copyright: @ 2021 The Author(s)

Published by Human Resource Management Academic Research Society (www.hrmars.com)

This article is published under the Creative Commons Attribution (CC BY 4.0) license. Anyone may reproduce, distribute, translate and create derivative works of this article (for both commercial and non-commercial purposes), subject to full attribution to the original publication and authors. The full terms of this license may be seen

at: http://creativecommons.org/licences/by/4.0/legalcode

Vol. 11, No. 8, 2021, Pg. 13 - 25

Full Terms \& Conditions of access and use can be found at http://hrmars.com/index.php/pages/detail/publication-ethics 


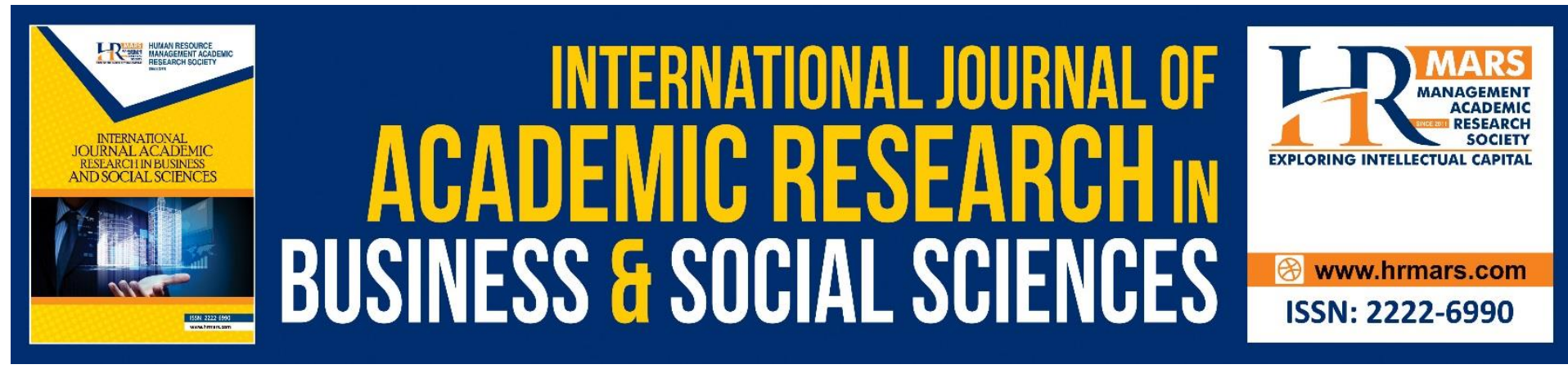

\title{
The Concept of Decolonization in Malaysia: A Philosophy Perspective
}

\author{
Nasruddin Yunos and Nazri Muslim \\ School of Liberal Studies, Universiti Kebangsaan Malaysia, 43600 Bangi , Selangor, \\ Malaysia \\ Email: nazrim@ukm.edu.my
}

\begin{abstract}
Colonization refers to the process of either an action or deed that makes a place, territory, or country a colony. The term decolonization can be defined as 'the process by which the colonial powers shift institutional and legal control over the territory'. Through this discussion of decolonization (decolonization), the background of physical colonization in Malaysia will be explained which eventually left epistemological colonization after independence. In addition, Descartes' views on the issue of the separation of mind and body, which affect the epistemology of world society today, are also discussed. Western colonialism in Malaya have an impact on the local community aspect of scientific epistemology. Following the currents of modern, post-modern and meta-modern times now, the challenge is becoming stronger due to the current of information technology that is running so fast. The Cartesian Dualism that was born and developed in Europe eventually gave rise to the ideology of selfishness, anthropocentrism and eurosentrism. These three beliefs are the root of the problems that also plague the community in Malaysia. Therefore, the process of decolonization is important to validate this notion.
\end{abstract}

Keywords: Decolonization, Philosophy, Malaysia, Colonial, Cartesian Dualism

\section{Introduction}

This article will discuss some basic things related to metaphysics. The discussion begins with understanding the meaning of colonization and decolonization. Furthermore, the discussion focuses on the concept of Cogito Ergo Sum and Cartesian Duaism which also affects the epistemology of Malaysian society. The phenomenon of the Destruction of NatureAnthropogenic and the emergence of Human Anthropocentrism/Egoism/Egological started from the Philosophy of Descartes, namely Cogito Ergo Sum (Cartesian Dualism). Efforts of decolonization by legitimizing Human Anthropocentrism Destroying Nature The Eruption of Cartesian Dualism Philosophy based on the development of Colonization / Colonization Epistemology / Eurocentrism is discussed further. This section concludes with a discussion on decolonization efforts through the Integrated / Prosperous / Ecological Human approach. Also discussed is the impact of colonialism on Malaysia from the aspect of materialism and nonmaterialism. 


\section{Meaning of Decolonization}

According to the Dewan Bahasa dan Pustaka Dictionary, colonization refers to the process of either an action or deed that makes a place, region, or country a colony. Horvath (1972) states that, colonialism is a form of domination i.e. control over the territory or behavior of another group by another foreign group. According to Fieldhouse (1981), colonialism refers to the state of political, economic and intellectual domination of the country. It can be concluded that colonialism in general is the formation of a colony by a stronger colonial power i.e. a form of colonialism that dominates and takes advantage of a weaker government (Mokhtar \& Samsudin, 2016). The term decolonization can be defined as the process by which the colonial powers shift institutional and legal control over the territory'.

Decolonization is also the process by which subordinate territories become sovereign and independent states (Shaw \& Colombijn, 2009). Decolonization also refers to the removal of colonial ideologies that aggravate and weaken the soul of the colonized society (Sabrin, 2013). Sabran (2016) has raised an interesting question that is whether the society and the people in this country are independent in terms of soul and mind? In order to be a truly independent society, the people must be free from any control and shackles from outsiders in physical or mental aspects. However, this is difficult to control in this age of technology because social media has a strong influence in society.

Colonial knowledge is a field of knowledge that was emerged in response to Western colonialism and keeps on growing as a part of decolonization struggles. The interest about colonial knowledge arose among scholars and intellectuals from the previously colonized countries as they are concern about the impact of knowledge on their entire lives and their respective communities. Colonial knowledge discusses various aspects faced by postcolonial nations, including the element of epistemology (Shamsul, 2011). In the Malaysian context, S.H. Alatas discussed about the colonial kowledge through his writings such as Stamford Raffles: Schemer or Reformer? (1976); The Myth of the Lazy Native (1977) and Intellectuals in Developing Societies (1977). While S.M.N. Alatas has criticized and refuted the views of some Western orientalist scholars' interpretations of the original texts of several Islamic figures in the Malay World, such as the writings of al-Raniri and Hamzah Fansuri (Al-Attas 1966; 1968; 1970). Recently, colonial knowledge has also been discussed in relation to Islamic law in the community of Malaya (Halim, 2018), from the perspective of Maqasid Syariah (Ahmad Farid et al, 2017), it's impact on Islamic studies in Malaysia (Affandi et al., 2017) and it's impact on the museum institutions in Malaysia (Affandi et al., 2017).

As part of decolonization discussions in Malaysia, this paper on the other hand, is discussing specifically on the impact of colonization from philosophical perspectives. It is very crucial to analyze this aspect of knowledge as epistemology is one of the major impacts left by the colonial on the postcolonial nations like MAlaysia (Baharuddin, 2011).

The Phenomenon of Nature-Anthropogenic Destruction and the Emergence of Human Anthropocentrism, Egoism, Ekological started from the Philosophy of Descartes Cogito Ergo Sum (Cartesian Dualism)

As a result of the stream of modern thought or modernism, which tends to be rational, secular, liberal and prioritizes scientific and economic progress, then there is a debate 
regarding the philosophy of the human self itself. The mind-body problem became the main focus of the idea of Cartesian Dualism brought by Rene Descartes.

The idea of Cartesian Dualism defines the soul and body as distinct and separate entities/substances. What is proven to exist is the intellect, in contrast to the body and at the same time gives the understanding that the intellect is a fact of existence whereas the body as a machine is run by the intellect. For Descartes, man consists of two beings, the soul (mind) and the body (senses). For example in looking at nature, this idea of dualism concludes that nature is lifeless and can be treated at will. The spiritual (soul) aspect of nature is doubtful. Therefore, the living realm is a doubt and untrue. Thus, it can be concluded that, this stream of modern Western thought nurtures skeptical thinking in the search for truth.

Rene Descartes was a rational-minded philosopher of the mind alone. All things that he thinks and considers to be true are existent, irrational and intangible content is illusory or does not exist at all. Apart from Cartesian Dualism, Descartes also brought the ideology of Cogito Ergo Sum which means "I think then I have". This ideology of Cartesian Dualism and Cogito Ergo Sum eventually led to the distortion of human and environmental values. The basic ideology rooted in the minds of people in the West and brought to Malaya through the process of colonialism. This understanding influences modern thinking in various aspects including in the fields of science, social, politics and economics. At the very least, this ideology of Cartesian Dualism gave birth to four main ideologies, namely Naturalism, Materialism, Atheism and Reductionism.

\section{Naturalism}

Initially, this philosophy was founded by Luecippus and Democritus who explained that the universe is divided into two namely space and atoms, after which it cannot be divided by anything else. In general, this understanding accepts nature as the whole of reality. Where, this reality is understood by things that can be seen with the senses (physical realm), and determined by the laws of nature'. The basis of this understanding also accepts the scientific method but with everything stems from nature. Rousseeau, a leading figure of this ideology argued that the best way for a human being to live on earth is to get closer to nature.

\section{Materialism}

This philosophy comes from the Greek word 'materia' which means matter that is matter and mass. This belief has long been developed in Greek times by Democritus. In the 18th century, the philosophy of materialism was sparked by the Western philosopher Hobbes. He is also known for his reputation as the Father of Atheists. The materialism he espoused did not accept God and only accepted religion if it was practical. The philosophy of Naturalism and Materialism has to do with the philosophical stream of Realism embraced by philosophical figures such as Francis Bacon.

\section{Atheism}

The word comes from the Greek 'atheos' which means 'without God'. Atheism is a belief that denies the existence of God and the supernatural. In short, this ideology rejects the ideology of Metaphysics and adheres only to the logic of reason alone. Atheism emerged in stages from the Enlightenment to the Industrial Revolution and the Scientific Revolution. This ideology reached its peak during the French Revolution and in connection with that, France became 
the first atheist country. Many philosophers supported this belief such as Karl Marx, Sigmund Freud and Albert Einstein.

\section{Reductionism}

This understanding describes a complex phenomenon with less complex or simpler phenomena. In other words, it breaks down complex things into constituents of a more specific nature. This belief is divided into two forms, namely Positivism and Scientism. Positivism is an ideology that assumes that knowledge is solely based on experience and definite knowledge. Something unreal and obvious will be removed. Whereas, Scientism is the belief that scientific methods and approaches can be applied to all things and Science is the most valuable view. Reductionism can be clearly seen in the learning system in schools or universities today.

\section{Destroying Humans Anthropocentrism Destroys Nature The Eruption of the Philosophy of Cartesian Dualism based on the development of Colonization, Epistemological Colonization and Eurocentrism}

Cartesian Dualism has a wide range of negative effects on society. This ideology promotes the ideology of selfishness, anthropocentrism and eurosentrism. These three beliefs are rooted in society which in turn has a detrimental effect on human and environmental relations.

\section{Egoism}

The word comes from the Latin word ego which means 'I am'. This philosophy was founded by the German philosopher Friedrich Nietzsche. The philosophy of Egoism is principled that an individual should perform an action for his own benefit and considers this act to be good because it is selfish, not others. The characteristics of Egoism can be divided into two namely Psychological Egoism and Ethical Egoism. Psychological egoism is of the view that every individual is selfish or selfish in his mind. Ethical egoism, on the other hand, emphasizes that every individual should be selfish in his actions.

Nietzsche opposed the issue of social morality based on the rules of society. Nietzsche was he divided society into two groups namely the aristocracy consisting of the rich and the common people, consisting of the less fortunate and the weak. For Nietzsche, 'creating' God or believing in religion and the effort to introduce this moral rule was only to protect the common people and it led to rebellion. Although one's ego level is based on one's point of view, the goal is still the same, which is selfishness. Individuals who accept this ideology are often individualistic and indifferent to exploiting, oppressing and manipulating others.

\section{Anthropocentrism}

The word comes from the Greek word ánthrōpos which means human. This belief believes that human beings are the most important entity in the universe. Socrates was the first philosopher to formulate this philosophy and then supported by modern philosophy, especially in the Renaissance. Anthropocentrism is principled that the ultimate value is human beings as precious beings and that something non -human in this universe is merely a tool to human beings to satisfy their interests and help human beings to survive. Furthermore, human beings are considered to be rulers over the universe who can do anything to this universe. However, Anthropocentrism began to be criticized by activists in favor of animals and nature because these two elements were also important for the balance of ecosystems 
on earth. An example related to this belief is the case of illegal logging in forests. The authorities to illegal logging activities ignore the long -term adverse consequences to the forest ecosystem because they only think of the rewards that benefit themselves. Thus, Anthropocentrism is a key concept in environmental philosophy because this understanding is often associated with the root causes of problems created by human actions.

\section{Eurocentrism}

Eurocentrism refers to the attitude of taking European traditions and values such as beliefs or thought as a universal pattern. This tendency leads society to elevate the culture, social organization and political system of Europe is the most superior in the world. From that superiority, it is said that Europe is destined to lead the world. This European -centered belief gives rise to a tendency to interpret non -European history and culture from a Western point of view. J.M. Blaut describes such beliefs and approaches as a form of European -centered cultural diffusion theory (Eurocentric diffusionism) which believes in Europe as the trigger of human civilization either worldwide. According to Blaunt, this theory is a theory of how cultural processes or civilizations move and creep from one center to another.

\section{Decolonization through an Integrated, Prosperous and Ecological Human Approach}

In short, Cartesian Dualism has given birth to egoism, anthropocentrism and eurosentrism which have contributed to environmental damage and influenced the intellectuals of society in Malaysia during the colonial era. Thus, in response to such circumstances, epistemological decolonization efforts need to be undertaken. Among the efforts that can be done are:

\section{Decolonization of Egoism with Inferiority and Confession}

Western epistemological colonization has led to the birth of egoism which considers a value to be good when it benefits the individual. Therefore, this egoism can be eliminated by nurturing the nature of humility and the application of the value of tawaduk or "the more full, the more submissive".

\section{Decolonization through an Integrated, Prosperous and Ecological Human Approach}

Western epistemological colonization has given birth to anthropocentrism that centers this life on human beings alone. This clearly leads to exploitation and destruction of the environment. To curb this understanding, the idea of Insan Sejahtera \& Ekologikal (Happay Man \& Ecological Man) should be highlighted. Human beings here mean, unique beings who have intellect and mind and the best and have a high rank in the sight of God. Prosperity, on the other hand, means good values, peace and tranquility. While ecologically, human beings are aware of the relationship and balance between nature and humans. Therefore, the concept of succeeding in this integrated, prosperous and ecological human being is to produce individuals who have high morals, morals, and preserve the environment. Man must be aware of his relationship with the environment. The environment is not to be exploited for human benefit alone, even this environment needs to be maintained for the well-being of life. The environment plays a very important role for the balance of this earth.

\section{Decolonization of Eurocentrism with Local Wisdom (Occidentalism)}

Western epistemological colonization has also given birth to Eurocentricism which has caused Malaysians to look at themselves through the eyes of Westerners. This has a negative impact on the identity of Malaysian citizens themselves. For example, independence fighters have 
been declared rebels in Malaysian historical writings by Western scholars. Malaysians need to realize that there is no need for outsiders to interpret ourselves and our society. We who know more about our society. The idea can be highlighted through the application of the understanding of Occidentalism in the realm of science. In addition, efforts to re -popularize various forms of local prowess, skills and knowledge need to be developed. Various aspects of local genius belonging to the people of this country which is a heritage need to be revived. Subsequently, the local wisdom was developed together with the efforts of Occidentalism in strengthening the intellectual and identity of Malaysian citizens.

\section{Realizing Your Own Reference Thinking}

The process of building thinking according to one's own mold is very important to disprove the mold of colonial thinking from the society in Malaysia. Apart from developing the country in line with current economic development, our society should also be nurtured by changing the concept of development to a more balanced sustainable development not only looking at Gross National Product (GNP) without looking at the impact on the environment.

\section{The Impact of Colonialism on Malaysia from the Perspective of Materialism New Town Development}

Association of British administration in Malaya seeks to maximize financial profit. The emergence of the new city was a physical effect brought on by British colonialism. Means the change from a small town or village to a city. The process of urbanization occurs as a result of rapid economic development. Towns close to mining areas will experience an increase in population. The development of mining has added to the function of the city. Among the cities that exist due to ore mining activities are Kuala Lumpur, Taiping, Ipoh, Seremban. The emerging city serves as a business and administrative center and is equipped with infrastructure facilities. Most of its inhabitants made up of Chinese society than in India and Indonesia. The community is tied to the village. While the Indian community is concentrated in rubber plantations (Nordin and Hussin, 2014).

\section{Unbalanced Development}

The development of the transportation system also influenced the existence of new cities. The development of Kuala Lumpur involves the development of infrastructure, especially roads and major railways. Production of tin and rubber, making Port Klang, Melaka and Penang emerged as an important port city in Malaya. The city of Kuching has emerged as a center for the collection and export of gambier and black pepper since the 1840s. However, the construction of infrastructure by the British was more concentrated in areas that could provide economic benefits to them. Therefore the west coast of Malaya preferred to the east coast of the Malay Peninsula.

\section{Development of Agriculture -Related Private Companies}

British focus on raw material production and development of manufacturing enterprises in Malaya slow because of manufactured goods imported to give competition to local products. Imported goods are better and cheaper than local goods. The British prioritized the production of raw materials. In the 20th century factory enterprises began to grow mainly tin ore and rubber. Among the manufacturing companies that exist are Shoes-Brick and Fung Keong, Rubber-Kinta Rubber Works, dredgers, small ships and rubber processing machines- 
United Engineers. The tin smelting company-Straits Trading Company. Pineapple canning plant-based in Johor.

\section{Development of Transportation System}

Developments in the field of mining and plantation cause transportation and communication systems in Malaya. The railways are:

a) 1885-railway connecting Taiping with Port Weld

b) 1889-connecting Kuala Lumpur with Port Swettenham

c) 1891-connecting Seremban with Port Dickson

d) 1895-between Ipoh and Tapah Road with Telok Anson

e) 1904-tin mining area has railway service

Road construction is also growing, namely:

a) $1895-2400 \mathrm{~km}$ long paved road network was built in Perak and Selangor

b) 1911-the road from Seberang Prai to Melaka was completed

c) 1911-1928-road from Perlis to Singapore completed

\section{Development of Health Institutions}

The Malay community before the arrival of British colonists mostly traditional medical practice and subject to the handler or shaman to cure illnesses. British colonial Malaya introduced the modern medical system in the presence of doctors, nurses, clinics, the Red Cross and health centers. The establishment of health centers at an early stage is to help treat farm workers as well as locals suffering from Malaria, beriberi, cholera and so on. Although initially it was not well received by the people of Malaya, over time more and more people have visited the village dispensary or medical teams move to get medical services. Over time these health centers have grown from urban to rural areas (Nordin and Hussin, 2014).

The mass influx of foreign labor resulted in a sharp increase in population, overpopulation, unsatisfactory housing and workplace, insufficient supply of clean water, spread of infectious diseases. Thus, the British government has sought to improve health services by:-

a. Establish a hospital

b. Set up a small health center

c. Establish medical research institutions

For example, private hospitals such as Tung Shin Hospital were built and provided health services to tin miners. The British government set up a board called the Sanitary Board to oversee the cleanliness of the city.

\section{Remains of Historic Monuments}

Indirect effects of the results of British colonization in the past were monuments or buildings that became the effect of British colonization of the country. Among the remnants of the history of foreign colonization in this country are found in Melaka traces of Portuguese and Dutch occupation, and some states in Malaysia still keep some old buildings of British and Japanese colonization. These relics have also contributed to the development of tourism in the country and this has indirectly also become one of the foundations to attract foreign tourists to come to the country (Nordin and Hussin, 2014). 


\section{The Impact of Colonialism on Malaysia from a Non - Materialism Perspective Democratic System}

Democracy was brought by the west at one time and at one time had a great influence in the administration of Malaya formerly feudal Emirate considers the king as an absolute leader. The democratic system is very different from the Emirate system practiced by the Malays past. In this democratic system, the sovereignty and decisions of the country must be made by the people using the majority vote that chooses to make a decision. The election of leaders in a democratic way is also done based on the views, support and aspirations of the people towards the candidates who are deemed worthy. The selection of leaders is done in elections held (Nordin and Hussin, 2014). This democracy has in fact limited the power of the sultan or king who before, they were the absolute rulers in the administration of their respective states. In Malaysia, our country has adopted Parliamentary Democracy. Malaysia has adopted the concept of parliamentary democracy from the beginning of independence until now.

\section{The law}

There is dualism in the legal system in Malaysia, namely Civil and Syariah. Syariah Courts are removed from the Federal Court hierarchy. It is placed under state authority. Federal law has limited the powers of the Syariah Court. British law is fully applied in the Civil Courts. Islamic law limits its jurisdiction only in matters of family, inheritance and very limited criminal offenses. Malay rulers as the head of the Islamic state has limited powers. British law has influenced the Judicial System.

\section{Education}

Before the arrival of the British in Malaya, the Malayan people already have their own education system, namely religious education and school hut. In that time they have not been introduced secular education among the Malays. After the arrival of the British, some vernacular schools was introduced as the establishment of the Penang Free School, which is the first English school was built in Malaya. There was also the Malay, Chinese and Tamil schools built for the people of Malaya education. However, most of these schools are concentrated in urban areas. While higher education for the Malays were also held by the British that MCKK or Malay College Kuala Kangsar and MPSI or Maktab Perguruan Sultan Idris (Nordin and Hussin, 2014).

Establishment of the English School in Malaya at that time was an opportunity for the people of Malaya learn English and continue their studies to a higher level. In addition, the British also introduced Rumi to the people of Malaya than Jawi script used by the Malays at that time.

The direction of education during the British colonial period aimed at restricting the opportunities for Malays to develop their talents, to separate them from the socio-economic development of the country. Overall, education in the British colonial period is discretionary or laissez-faire because there are five types of education that has been established does not have to be uniform, namely English, Malay, Chinese, Tamil and Muslim. Each type of school has a different philosophy and direction of teaching and curriculum. As a result of this imbalance, the British have made a study. Following on from that, several reports have been drafted including:

- Barnes Report 1959 
- Fenn-Wu Report 1951

- Education Ordinance 1952

- Razak Report 1956

This report has brought about a major change in the direction and philosophy of education in our country.

\section{Social}

Social influence of the west as we understand them are thinking of the Malays who are starting to be more open. This open mind can be seen in the beliefs of our society on things called taboos, tips and others. Normally regarded as a taboo in the community of law that must be obeyed and if someone is breaking taboos. This way of thinking has started to change since the advent of the west and considers these things more to be nonsense. Moreover, in the social aspect of the family the developments taking place in the West in relation to the idea that the family is no longer a functional unit, and therefore need not be defended, are worrisome. The West is trying to find other alternatives to replace the family institution and among the proposed alternatives are cohabitation without marriage, same -sex couples, single parenthood, group living, and professional upbringing of children.

\section{The Formation of a Plural Society}

During the British colonial period, it was found that the three races did not interact at all. May be asserted Malaya belonged to the Malays, also belong to the commercial economy of China and India as belonging to British politics to the extent that the Malays left behind. Actually there are several factors that make the Malays are not involved in the commercial economy. One of the reasons is the British themselves with their policy of oppressing the natives as well as the 'Breaking the Order Policy' carried out by the British during its occupation. The second period refers to the era towards independence. In this case it can be seen that there is a relationship between the races. Malay United Malays National Organization (UMNO), China and the Malayan Chinese Association (MCA) and India with Indian Congress Malaya (MIC) to form a political party that is based on their respective races but is under the umbrella of the Alliance (Nordin and Hussin, 2014). The result of a collaboration between race allows British agreed to grant independence to Malaya in 1957.

\section{Art}

The influence of western art can also be seen from two aspects, namely the aspect of architecture and musical performance. Western influences are actually clearly we can prove through the musical currents they bring to our world. Through these trends, the result is groups of artists who flow rock, ballad, pop, jazz and others. Too many streams of music are being brought in by the west into our world. The impact of the influence of these musics is not only highlighted by our country, but the whole world has also received its impact and tempiation. To some extent, these music genres actually further diversify the performing arts in our country. However, because of this too, our traditional art is beginning to be marginalized.

In addition, some of the architectural designs of the buildings found in our place are also evidence of western influence on us. Western-style construction can be seen on new buildings built with the concept of modernity. The construction of this building applies western features that are considered modern by the world. The art brought by Westerners has greatly 
influenced the world nowadays. In the field of music art for example, in addition to diversifying music genres, there are several image identities that emerge based on the flow of music they are involved in because each genre of music, has a different identity and image to the musician. For example, the images of rock and jazz singers are completely different. The image of a pop musician is also different from that of a rap. Through the diversity of images brought by them, this has had a detrimental effect on the image of our tradition because the things brought by the west are actually very easy to influence the world community including ourselves.

\section{National Spirit}

The national spirit or the spirit of love for the nation and country is a trait that must be present in all individuals who consider themselves citizens. This spirit will continue to grow in the soul of the nation as long as there is a certain power that tries to disrupt the country, religion and nation. In the context of colonial rule in Malaya, he has contributed greatly to the growth of nationalism in the country's population. The origin of the growth momentum was attributed to the role of colonizers who brought in foreign nations to Malaya to work in the rubber plantations and tin mines and the development of educational systems that have awaken the Malays to rise against foreign powers were so greedy rummage revenue collections country . The earliest was the opposition to British occupation by several individuals such as Dato 'Bahaman, Tok Janggut, Mat Kilau, Mat Salleh, Dato' Maharajalela and others. The second stage of resistance to British colonial government by the educated religious, Malay and English (Nordin and Hussin, 2014).

\section{Conclusion}

Western colonialism in Malaya have an impact on the local community aspect of scientific epistemology. The effects are still being felt to this day. Colonialism has impacted Malaysia either in terms of materialism or non -materialism which directly or indirectly, has influenced in terms of political, economic and social as well as thought. Following the currents of modern, post-modern and meta-modern times now, the challenge is becoming stronger due to the current of information technology that is running so fast. The Cartesian Dualism that was born and developed in Europe eventually gave rise to the ideology of selfishness, anthropocentrism and eurosentrism. These three beliefs are the root of the problems that also plague the community in Malaysia. Therefore, the process of decolonization to validate this understanding must be done.

Selfishness can be dispelled by the application of the values of humility and humility. Anthropocentrism, on the other hand, is dispelled through the concept of an integrated, prosperous and ecological human being. Meanwhile, Eurocentricism was eliminated with the application of the discipline of Occidentalism and local wisdom. In addition, new philosophical elements also need to be sown and nurtured in all aspects of community life. The main elements in the construction of a new philosophy are the concept of divinity and the concept of well -being. These two elements are very important to undermine the roots of Western ideology and in turn fend off the growing challenges of post-modernism and metamodernism. Thus, unity and togetherness in applying new philosophical elements into society is very important. This journey is still long and demands the involvement of every Malaysian citizen. 


\section{References}

Abdillah, J. (2014). Dekonstruksi Tafsir Antroposentrisme: Telahan Ayat-Ayat Berwawasan Lingkungan. Kalam: Jurnal Studi Agama dan Pemikiran Islam. 8(1): 68-71

Abdul Jalal, A. F., Abdul Rahim, R. A., Ismail, H., \& Abdul Razak, M. I. (2017). Pengaruh Ilmu Kolonial Dalam Permuziuman Di Malaysia: Satu Analisa. e-Academia Journal.6(1): 127141.

Abdul Rahim, R. A., and Kahal, S. M. (2017). Ilmu Kolonial Dan Islamisasi Alam Melayu: Analisis Kritikal. Sejarah: Journal of Department of History. 26(1). 33-49.

Abdul Jalil, A. F., Abdul Rahim, R. A., Ismail, A. I., \& Rosele, M. I. (2017). Ilmu Kolonial di Malaysia: Perspektif Maqasid Syariah. Al-Banjari. 16 (1), Januari-Juni 2017, ISSN (Print) 1412-9507 ISSN (Online) 2527-6778

Amin, S. (2009). Eurocentrism: Modernity, Religion, and Democracy. New York: Monthly Review Press.

Arifin, M. (2018). Epistemologi Rasionalisme Rene Descartes Dan Relevansinya Terhadap Penafsiran Al-Qur`An. IImu Ushuluddin, 17(2): 147-157

Asfar, T., \& Asfar, A. (2019). Pendidikan Masa Renaissance: Pemikiran dan Pengaruh Keilmuan Pendidikan. Indonesia: Universitas Negeri Makassar.

Ashton, T. S. (1948). The Industrial Revolution (1760-1830). London: Oxford University Press.

Azmi, M., \& Samsudin, M. (2016). Kolonialisme British Terhadap Negeri-Negeri Melayu Bersekutu Ketika Perang Dunia Pertama. Journal of Social Sciences and Humanities. 2: 83-95.

Harian, B. (2007). Penjajahan British dan Perjuangan Kemerdekaan. Malaysia: Berita Harian.

Boslaugh, S. E. (2016). Anthropocentrism. Britannica. Diperoleh 30 November 2020 dari https://www.britannica.com/topic/anthropocentrism

Dewan Bahasa dan Pustaka. (n.d.). Antroposentrisme. Diperoleh 30 November 2020 dari https://prpm.dbp.gov.my/Cari1?keyword=Antroposentrisme

Dewan Bahasa dan Pustaka. (n.d.). Egoisme. Diperoleh 30 November 2020 dari https://prpm.dbp.gov.my/cari1?keyword=egoisme

Dewan Bahasa dan Pustaka. (n.d.). Kolonisasi. Diperoleh 30 November 2020 dari http://prpm.dbp.gov.my/cari1?keyword=kolonisasi

Duignan, B. (2020). Enlightenment. Britannica. Diperoleh 30 November 2020 dari https://www.britannica.com/event/Enlightenment-European-history

Encyclopedia.com. (2020). Philosophy of Science: Baconian and Cartesian Approaches. Diperoleh 30 November 2020 dari

https://www.encyclopedia.com/science/encyclopedias-almanacs-transcripts-andmaps/philosophy-science-baconian-and-cartesian-approaches

Fieldhouse, D. K. (1981). Colonialism 1870-1945: An Introduction. London: Weidenfeld and Nicolson.

Fritz, K. V. (2017). Western-philosophy: Medieval Philosophy. Britannica. Diperoleh 30 November 2020 dari https://www.britannica.com/topic/Westernphilosophy/Medieval-philosophy

Ismail, H. (2018). Perspektif IImu Kolonial tentang Hukum Islam dan Masyarakat di Tanah Melayu: Analisis Terhadap Karya-karya Terpilih. M.A. Thesis. Universiti Malaya: Akademi Pengajian Islam.

Horvath, R. (1972). A Definition of Colonialism. Current Antropology. 13(1):45-57.

Jansen, J. C., \& Osterhammel, J. (2013). Decolonization: A Short History. United Kingdom: Princeton University Press. 
Krishan, K. (1995). From post industrial to post modern society, New Theories of The Contemporary World. USA: Blackwell Publishers

Kuiper, K. (2020). Modernism. Britannica. Diperoleh 30 November 2020 dari https://www.britannica.com/art/Modernism-art

Majid, S. M. (2016). Eurosentrisme Dan Pemaparan Imej Orang Melayu Zaman Kolonial British Sehingga 1900, Disertasi Sarjana Sastera, Universiti Sains Malaysia.

Mingst, K. (1980). French Intervention in Africa: Depedency or Decolonization. London: Africa Today.

Niller, E. (2019). How the Second Industrial Revolution Changed Americans' Lives. History. Diperoleh 30 November 2020 dari https://www.history.com/news/second-industrialrevolution-advances

Nordin, M dan Hussin, H. (2014). Pengajian Malaysia. Edisi Kelima. Kuala Lumpur. Penerbit Fajar Bakti.

Osler, M. J., Brush, S. G., \& Spencer, J. B. (2019). Scientific Revolution. Britannica. Diperoleh 30 November 2020 dari https://www.britannica.com/science/Scientific-Revolution

Abd. Rahim, R. A., Abdul Jalal, A. F., Ismail, A. H., Ismail, H., Abd. Kadir, N. A., Rosele, M. I., \& Kamaruddin, N. K. (2017). Ilmu Kolonial dan Impaknya Pada Pengajian Islam di Malaysia. Ulwan's Journal. (1): 97-124.

Abdul Rahim, R. A., Abdul Jalal, A. F., Ismail, H., Ismail, A. H., \& Abd Razak, M. (2017). The influence of colonial science on museums in Malaysia: an analysis. e-Academia Journal. 6 (1): 127-141.

Sabran, M. S. (2016). Penjajahan Minda Gen-Y. Malaysia: Kosmo.

Baharuddin, S. A. (2011). Ilmu Kolonial dalam Pembentukan Sejarah Intelektual Malaysia: Sebuah Pandangan. Bangi: KITA.

Shaw, A., \& Colombijn, F. (2009). Introduction-Decolonization And Urban Change In The Asian City. Urban Geography. 30 (8): 809-814.

Stukus, D. R., Patrick, M. D., \& Nuss, K. E. (2019). Social Media for Medical Professionals. Switzerland: Springer.

Touraine, A. (1995). Critique of modernity. Translated by Daved Macey. Oxford: Blackwell.

Xypolia, I. (2016). Eurocentrism and Orientalism. The Encyclopedia of Postcolonial Studies. Diperoleh 30 November 2020 dari https://www.researchgate.net/publication/293958727_Eurocentrism_and_Orientalis $\mathrm{m}$

Yaacob, S., \& Najmuddin, H. (2008). Rene Descartes (1596-1650) Dan Metode Cogito. Jurnal Usuluddin. (27): 121-140.

Zartman, I. W. (1976). Europe and Africa: Decolonization or Dependency?. Foreign Affairs. 54(2):325-343. 